\title{
Locally Advanced Gastroesophageal Junction Adenocarcinoma
}

National Cancer Institute

\section{Source}

National Cancer Institute. Locally Advanced Gastroesophageal Junction Adenocarcinoma. NCl Thesaurus. Code C162759.

Gastroesophageal junction adenocarcinoma that has spread to nearby tissues or lymph nodes. 